\title{
A swallowed metal nail entrapped in the right psoas muscle
}

\author{
İhsan Yıldız, M.D., Yavuz Savaş Koca, M.D., İbrahim Barut, M.D.
}

Department of General Surgery, Süleyman Demirel University Faculty of Medicine, Isparta-Turkey

\begin{abstract}
Foreign body ingestion can be caused by many factors, including hallucination in patients with mental retardation. Most ingested foreign bodies are naturally discharged, though surgical intervention is necessary in some cases. Endoscopic intervention often leads to successful outcome, though open surgery may be required in certain instances. A 29-year-old mentally retarded woman presented to emergency services with a 2-day history of right lumbar pain that increased with movement. Physical examination revealed no specific sign beyond palpable tenderness in the right lumbar region. Radiological examination revealed a metal nail in the upper right quadrant, stretching obliquely toward the retroperitoneum. Endoscopy failed, and the nail was extracted via laparotomy. Foreign body ingestion may occur in patients of any age, but is more common in the pediatric population and in patients with mental retardation. Commonly ingested foreign bodies include daily objects, toys, and dentures, though they may differ in patients with mental retardation. The treatment of such cases requires a diversity of methods and experience. Foreign body ingestion should be kept in mind when a patient presents with pain in the right lumbar region, particularly in patients with mental retardation.
\end{abstract}

Keywords: Duodenal perforation; swallowed foreign body.

\section{INTRODUCTION}

Foreign body ingestion may intentionally or unintentionally occur. Unintentional foreign body ingestion is frequently observed in patients aged between 3 months and 6 years, as well as in the elderly population. However, it may also be the result of psychiatric disorders involving hallucination in patients with mental retardation. Cases of intentional foreign body ingestion have also been reported. ${ }^{[1,2]}$ Commonly ingested objects include coins, needles, pins, jewelry, toy parts, teaspoons, nails, batteries, dentures, fish and chicken bones, and items used to handle food, such as lollipop sticks. These objects may be made of plastic, metal, or toxic material. ${ }^{[1-9]}$

Most ingested foreign bodies are naturally discharged from the body within 4-6 days. However, serious complications in the gastrointestinal system such as obstruction or perfora-

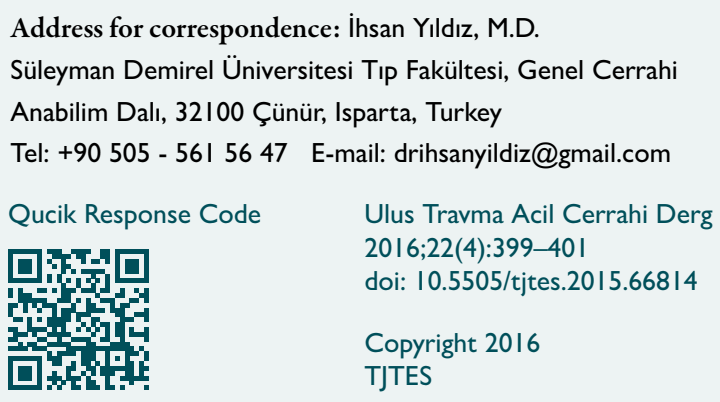

tion may occur, requiring surgical intervention. These complications may also be associated with clinical presentations such as nausea, vomiting, and acute abdomen, depending on the location and severity of the obstruction and perforation. [1,5-9] Endoscopic approach is the method of choice in the treatment of ingested foreign bodies. However, laparoscopy and laparotomy may also be required in cases of perforation or obstruction. ${ }^{[2,5]}$ Following foreign body retrieval, treatment of mental disorder, if applicable, in order to prevent repeated ingestion, is of prime importance. ${ }^{[1]}$

Presently described were the clinical properties of a mentally retarded woman with repeated foreign body ingestion, who ingested a $12-\mathrm{cm}$ nail, which became entrapped in the right psoas muscle after perforating the third portion of the duodenum. Also described were reported diagnostic and treatment approaches.

\section{CASE REPORT}

A 29-year-old mentally retarded woman presented to the emergency department with a 2-day history of right lumbar pain. The family stated that the patient had a history of repeated foreign body ingestion. Physical examination revealed tenderness in the right lumbar on deep palpation. Results of other examinations were normal. White blood cell count was 12000 cells $/ \mathrm{mm}^{3}$ and other parameters were normal. Direct abdominal radiography revealed a radiopaque impression of 


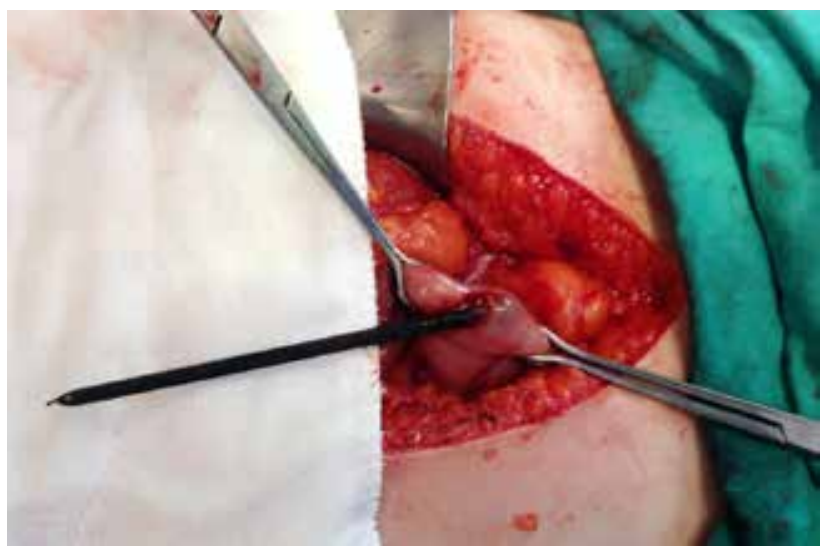

Figure 1. Removing of swallowed nail from stomach is shown.

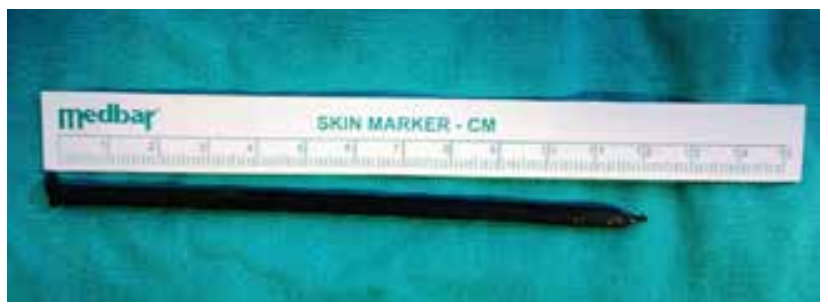

Figure 2. $12 \mathrm{~cm}$ metal nail removed is shown.

a metal nail in the upper right quadrant, directed downward (Fig. I). Computed tomography showed a foreign body suggestive of a metal nail perforating the third portion of the duodenum and entrapped in the right psoas muscle (Fig. I).

Endoscopic intervention was attempted, though no contact was made with the nail. Laparotomy was performed under general anesthesia. Upon intraabdominal exploration, the inner abdomen was clean, the intestines were normal, and exploration confirmed that the nail had perforated the third portion of the duodenum and was entrapped in the right psoas muscle. The nail was manually mobilized into the stomach and extracted by gastrostomy, as endoscopic extraction may have caused damage to surrounding tissues. Following extraction, it was revealed that the nail and its metal structure had been impaired (Fig. 2).

The duodenum was freed using Kocher's maneuver, and the perforation tract was explored. No inflammation or localized peritonitis was observed. Surgery was concluded following insertion of a soft drain into the surgical site without impairment of the integrity of the fibrotic tract. The patient had psychiatric consultation and was discharged on the seventh postoperative day.

\section{DISCUSSION}

Foreign body ingestion can occur accidentally or intentionally, and is most frequently observed in children at development stages and in patients with mental retardation. ${ }^{[1,2]}$ In mentally retarded patients, cases similar to the present, of foreign body ingestion resulting from hallucination, have been reported. ${ }^{[1]}$ The present patient had psychiatric consultation in the early postoperative stage, upon the assumption that her mental retardation may have led to repeated foreign body ingestion.

Foreign body ingestion and its complications are rare, though they remain a serious clinical problem. Most ingested objects are naturally discharged. ${ }^{[1]}$ The period of extraction typically lasts for 5 days, depending on the size and structure of the ingested object. An orally ingested object passes through the oropharynx, pharynx, esophagus, cardia, pylorus, duodenum, small intestine, and colon, sometimes leading to obstruction and perforation at the anorectal level before penetrating into the rectoanal region. ${ }^{[5,7-9]}$ Objects smaller than $6 \mathrm{~cm}$ and those with a structure thinner than $2 \mathrm{~cm}$ require no intervention and are naturally discharged. ${ }^{[5]}$ In some cases, the ingested object remains in the body with no symptoms, and leads to unexpected complication after a long period. Misra et al. suggested that conservative treatment of asymptomatic cases is ideal, and that intervention should be performed following onset of first symptom. ${ }^{[1]}$ Exact time of ingestion was unknown in the present case, though the patient's family guessed that the nail had been ingested approximately 2 months prior, and that symptoms had begun 2 days prior to admission.

Approximately 10-20\% of ingested objects are extracted by endoscopy, while less than $1 \%$ require surgical intervention, performed in cases of perforation, obstruction, organ injury, and entrapment in surrounding tissues. ${ }^{[1,7-9]}$ In the present patient, the nail was entrapped in the right psoas muscle after perforating the posterior wall of the third portion of the duodenum, with no sign of acute abdomen, a rare case. It was believed that perforations in the retroperitoneal area were not related to the peritoneum, and that pain was the result of movement of the nail caused by entrapment of the psoas muscle.

Gastric and duodenal foreign bodies are often extracted by endoscopy. ${ }^{[2]}$ However, endoscopic mobilization of the nail failed in the present case, and the nail was manually mobilized into the stomach through the duodenum. The nail was extracted after gastrostomy was performed on the anterior wall of the stomach, and the stomach was sutured. The duodenum was Kocherized, and the fibrotic tract was extensively dissected. However, the tract was not opened, as repair would have been difficult and may have lead to high-output fistula.

\section{Conclusion}

Entrapment of an ingested nail in the psoas following closed duodenal perforation is a very rare clinical occurrence. As evidenced by the present case, foreign body ingestion should be considered when patients present with pain in the right lumbar region without indication of obstruction or acute abdomen, particularly in cases of mental retardation. 


\section{Conflict of interest: None declared.}

\section{REFERENCES}

1. Misra S, Jain V, Ahmad F, Kumar R, Kishore N. Metallic sewing needle ingestion presenting as acute abdomen. Niger J Clin Pract 2013;16:5403. Crossref

2. Sai Prasad TR, Low Y, Tan CE, Jacobsen AS. Swallowed foreign bodies in children: report of four unusual cases. Ann Acad Med Singapore 2006;35:49-53.

3. Nijhawan S, Kumpawat S, Ashdhir P, Behl N, Jha A, Rai RR. Impacted nail in duodenum: endoscopic removal with a novel magnetic foreign body retriever. Endoscopy 2009;41 Suppl 2:62. Crossref

4. Hayek G, D'Assignies G. Images in clinical medicine. An unknowingly swallowed inedible toy. N Engl J Med 2013;369:2535. Crossref

5. Cho EA, Lee du H, Hong HJ, Park CH, Park SY, Kim HS, et al. An unusual case of duodenal perforation caused by a lollipop stick: a case report. Clin Endosc 2014;47:188-91. Crossref

6. Kim MJ, Seo JM, Lee Y, Lee YM, Choe YH. An unusual cause of duodenal perforation due to a lollipop stick. Korean J Pediatr 2013;56:182-5.

7. Başpinar I, Sahin S, Erdoğan G. Acute mechanical intestinal obstruction after ingestion of foreign bodies: a case report. [Article in Turkish] Ulus Travma Acil Cerrahi Derg 2010;16:92-4.

8. Celik S, Aydemir B, Tanrıkulu H, Okay T, Doğusoy I. Esophageal foreign bodies in children and adults: 20 years experience. [Article in Turkish] Ulus Travma Acil Cerrahi Derg 2013;19:229-34. Crossref

9. Cobanoğlu U, Yalçinkaya I. Tracheobronchial foreign body aspirations. [Article in Turkish] Ulus Travma Acil Cerrahi Derg 2009;15:493-9.

\section{OLGU SUNUMU - ÖZET}

\section{Sağ psoas kasına saplanan yutulmuş çivi \\ Dr. İhsan Yıldız, Dr. Yavuz Savaş Koca, Dr. İbrahim Barut}

Süleyman Demirel Üniversitesi Tıp Fakültesi, Genel Cerrahi Anabilim Dalı, Isparta

Yabancı cisim yutulması bilinçsiz ya da bilinçli olabilmektedir. Bilinçsiz olanların çoğu, üç ay-altı yaş arası çocuklarda, çok ileri yaşlarda, kazayla veya mental problemli kişilerde halüsinasyon gibi bir nedenle olabilmektedir. Bu cismlerin çoğu doğal yoldan atılmaktadır. İki gündür sağ lomber bölgede hareketle artan ağrı şikayeti ile acil servise getirilen, 29 yaşındaki mental retarde kadın hastanın fizik incelemesinde palpasyonla sağ lomber hassasiyet dışında bir özellik yoktu. Yapılan radyolojik değerlendirmede sağ üst kadranda retroperitona oblik olarak uzanım gösteren ve endoskopik olarak çıkartılamayan metal çivi laparotomi yapılarak çıkarıldı. Yabancı cisim yutulması birçok nedenle olabilmektedir. Mental retarde hastalarda halüsinasyonla yabancı cisim yutulması bildirilmekte ve aynı şekilde bizim hastamız da mental retarde idi. Ancak yutulan cisimin akut karın oluşturmadan sağ yan ağrısına neden olması olası bir komplikasyon olarak akılda tutulmalıdır. Özellikle mental retarde hastalarda olmak üzere sağ yan ağrısı ile gelen hastalarda yabancı cisim yutulması akılda tutulmalıdır.

Anahtar sözcükler: Duodenum perforasyonu; yabancı cisim yutulması.

Ulus Travma Acil Cerrahi Derg 2016;22(4):399-40I doi: 10.5505/tjtes.20।5.668।4 